\title{
Study of Breast Lump Cytology Evaluation in Pre-Menopausal Females
}

Dr. Sharique Ahmad*, Dr. Tanya Tripathi, Dr. Amina Maqbool, Dr. Zareena Farheen, Dr. Gauri Niranjan

Department of Pathology, Era's Lucknow Medical College and Hospital, Lucknow, Uttar Pradesh-226003, India

DOI: $10.36348 /$ sjbr.2020.v05i08.002 $\quad$ | Received: 09.08.2020 | Accepted: 17.08.2020 | Published: 19.08 .2020

*Corresponding author: Dr. Sharique Ahmad

\section{Abstract}

Palpable breast lumps in females are quite common which can be benign or malignant. After carcinoma cervix, carcinoma breast is the second most common cancer in females. Rapid diagnostic test like Fine needle aspiration cytology (FNAC) which is easy, quick, reliable, affordable and an OPD procedure can be utilized to plan the treatment accordingly. In this study various breast lesions of Pre-menopausal females were evaluated on the basis of cytological findings. This two-year study from January 2013 to December 2015 including 200 cases aspirated from palpable breast lumps of pre-menopausal females. Physical examination of breast lumps was done by palpation with aspiration and Cytological diagnosis was made. In this study most common benign breast lesion was fibroadenoma and among malignant ones medullary carcinoma was predominant (02 cases)

Keywords: Breast, Cytology, FNAC, pre-menopausal.

Copyright @ 2020: This is an open-access article distributed under the terms of the Creative Commons Attribution license which permits unrestricted use, distribution, and reproduction in any medium for non-commercial use (NonCommercial, or CC-BY-NC) provided the original author and source are credited.

\section{INTRODUCTION}

Breast cancers are one of the most common cancer in females worldwide \& it is also the major cause of fatality in women. Almost 80 to $85 \%$ is contributed by benign lesion \& remaining $20 \%$ are malignant in nature. Therefore for their proper management, distinction between the two is of utmost importance which can be done by cytological examination of breast lumps. Fine Needle Aspiration Cytology (FNAC) is one of the important steps among the triple test which is applied worldwide after physical examination \& radiology. FNAC is an established \& highly accurate method for diagnosing breast lesion.

Fine Needle Aspiration Cytology (FNAC) is $65-99 \%$ sensitive and $96-100 \%$ specific in diagnosis of palpable breast lumps.

\section{MATERIAL AND METHOD}

It is a retrospective study carried out from the data of North Indian tertiary care centre of period from January 2013 to December 2015 for the period of two years. All selected cases underwent FNAC in the mentioned period were retrieved. A proper written consent in patient's local language was obtained from each patient. Physical examination of breast mass by palpation was done along with the examination of axillary lymph nodes, FNAC was done by using needle attached to10cc/20cc disposable syringe. $95 \%$ alcohol fixed smears were prepared and stained with $\mathrm{H} \& \mathrm{E}$ (Hematoxylin \& Eosin) \& Leishman stain.

\section{Inclusion Criteria}

Pre-menopausal females with unknown primary diagnosis of breast mass.

\section{Exclusion Criteria}

1. Patient with recurrent malignancy.

2. Patient in whom Fine needle aspiration cytology (FNAC) was acellular.

3. Patient not giving written informed consent.

Cytological Slides were studied under light microscope \& cytological diagnosis were made under the standard cytological diagnostic protocol.

\section{OBSERVATIONS}

We included 200 breast aspirates of Premenopausal females with breast out of 200 patients, lump was located in right breast in $80(40 \%)$ cases, in $100(50 \%)$ cases in left breast and in $5(2.5 \%)$ cases it was bilateral (Table-1).

The most common site (Table-2) for lump was upper outer quadrant having $85(42 \%)$ cases followed by upper inner quadrant in $35(17.5 \%)$ cases. In $30(15 \%)$ cases, lump was subareolar and in $15(7.5 \%)$ cases it was diffuse involving all the quadrants. Of the total 200 cases, in 190 cases the aspirated material was adequate 
to confer the diagnosis, while in $10(5 \%)$ cases it was paucicellular with haemodilution precluding the definite opinion (Table 2). Various lesions on cytological evaluation diagnosis were inflammatory in $52(26 \%)$ cases, benign $123(61.5 \%)$, atypical $13(6.5 \%)$, and malignant $02(1 \%)$ cases (Table-3).

In Inflammatory lesions (Table-4), the maximum cases were of acute mastitis $43(82.7 \%)$ (Table-4) followed by Fat necrosis $05(9.6 \%)$ having history of previous surgeries and trauma. 02 (3.8\%) cases of granulomatous mastitis. In 02 (3.8\%) case there was chitinous wall, vegetative nuclei, with scattered lymphocytes, plasma cells, histiocytes, epithelioid cells \& foreign body giant cells and diagnosed as Cysticercosis.
In Benign lesions (Table-5), the maximum cases were of Fibroadenoma 60 (48.8\%). 30 (24.4\%) cases were of Fibrocystic disease, 02 (1.6\%) having Simple cyst which disappeared after aspiration, 20 (16.3 $\%$ ) cases were galactocele which also decrease in size after aspiration, $07(5.7 \%)$ cases of lactational adenoma, while spindle cell lesion have incidence of 04 (3.2\%) cases.

All 02 cases of malignant lesions were finally diagnosed as ductal carcinoma (Table-6). Majority of patient presented clinically with breast lump followed by fever, mastalgia \& breast enlargement (Table-7).

Table-1: Breast lumps Side wise distribution (Right, left \& bilateral)

\begin{tabular}{|l|l|l|}
\hline Side & Cases (200) & Percentage (\%) \\
\hline Right & 80 & 40 \\
\hline Left & 100 & 50 \\
\hline Bilateral & 5 & 2.5 \\
\hline
\end{tabular}

Table-2: Quadrant distribution of Breast lumps

\begin{tabular}{|l|l|l|}
\hline Quadrant & No of cases (200) & Percentage (\%) \\
\hline All & 15 & 7.5 \\
\hline Lower inner & 15 & 7.5 \\
\hline Lower outer & 20 & 10 \\
\hline sub areolar & 30 & 15 \\
\hline Upper inner & 35 & 17.5 \\
\hline Upper outer & 85 & 42 \\
\hline total & 200 & \\
\hline
\end{tabular}

Table-3: Cytomorphologic spectrum of Breast lumps

\begin{tabular}{|l|l|l|}
\hline Cytological diagnosis & Number of cases (200) & Percentage (\%) \\
\hline Inflammatory & 52 & 26 \\
\hline Benign breast lesions & 123 & 61.5 \\
\hline Atypical/probably benign & 13 & 6.5 \\
\hline Malignancy & 02 & 1 \\
\hline Unsatisfactory & 10 & 5 \\
\hline Total & 200 & 100 \\
\hline
\end{tabular}

Table-4: Breast lumps: Distribution of Inflammatory lesions.

\begin{tabular}{|l|l|l|}
\hline Cytological diagnosis & Number of cases (52) & Percentage (\%) \\
\hline Acute mastitis/abscess & 43 & 82.7 \\
\hline Granulomatous mastitis & 02 & 3.8 \\
\hline Fat necrosis & 05 & 9.6 \\
\hline Cysticercosis & 02 & 3.8 \\
\hline Total & 52 & 100 \\
\hline
\end{tabular}

Table-5: Breast lumps: Distribution of benign breast lesions

\begin{tabular}{|l|l|l|}
\hline $\begin{array}{l}\text { Benign Breast } \\
\text { Lesions }\end{array}$ & No of cases (123) & Percentage (\%) \\
\hline Fibrocystic disease & 30 & 24.4 \\
\hline Simple cyst & 02 & 1.6 \\
\hline Galactocele & 20 & 16.3 \\
\hline Fibroadenoma & 60 & 48.8 \\
\hline Lactational adenoma & 07 & 5.7 \\
\hline Spindle cell lesion & 04 & 3.2 \\
\hline Total & 123 & 100 \\
\hline
\end{tabular}


Table-6: Breast lumps: Distribution of malignant lesions

\begin{tabular}{|l|l|}
\hline Malignancy & No of cases (02) \\
\hline Ductal & 02 \\
\hline Medullary & 00 \\
\hline Malignant phylloides & 00 \\
\hline
\end{tabular}

Table-7: Diagnosis versus and complains of patients of breast disease

\begin{tabular}{|l|l|l|l|l|}
\hline Diagnosis & Breast pain & Breast lump & Fever & Enlargement of breast \\
\hline Fibrocystic disease (30) & $20(66.6 \%)$ & $25(83.3 \%)$ & - & - \\
\hline Simple cyst (02) & $01(50 \%)$ & $02(100 \%)$ & - & - \\
\hline Galactocele (20) & $10(50 \%)$ & $20(100 \%)$ & - & - \\
\hline Fibroadenoma (60) & $40(66.6 \%)$ & $60(100 \%)$ & $02(3.3 \%)$ & $06(10 \%)$ \\
\hline Spindle cell lesion (4) & $04(100 \%)$ & $04(100 \%)$ & - & $01(50 \%)$ \\
\hline Lactational adenoma (07) & $05(71.4 \%)$ & $07(100 \%)$ & - & - \\
\hline Acute mastitis/abscess (43) & $43(100 \%)$ & $40(93 \%)$ & $35(81.4 \%)$ & - \\
\hline Granulomatous mastitis (02) & $01(50 \%)$ & $02(100 \%)$ & $02(100 \%)$ & - \\
\hline Fat necrosis (05) & $04(80 \%)$ & $02(40 \%)$ & - & - \\
\hline Cysticercosis (02) & - & $02(100 \%)$ & - & - \\
\hline Ductul carcinoma (02) & $01(50 \%)$ & $02(100 \%)$ & - & - \\
\hline
\end{tabular}

\section{DISCUSSION}

In the present study, we included 200 breast lump cases in which cytomorphological study was done and cytological diagnosis were made. FNAC results were divided into inflammatory, benign, atypical/probably benign, and suspicious of malignancy, malignant \& unsatisfactory categories. Only in 10 cases (5\%) aspirate was unsatisfactory for evaluation where no diagnosis was made, rest aspirates were adequate and diagnosis were made. Unsatisfactory smears were slightly more than Mohammed et al ${ }^{[8]}$ unsatisfactory samples can be due to technical error. Repeat nature of lesion or inappropriate aspiration with diligence technique usually yields adequate material to confer cytological diagnosis, if still inadequate, core/incisional biopsy need to be opted.

In this study left side breast lump were more common this is in agreement with Meena et al., [9] and Reddy et al., [10].

Upper and outer quadrant was most commonly involved quadrant (42\%). This is in agreement with Rocha et al (45.20\%) [11] and Zuk et al., (42.2\%) [12].

In present study, among the benign lesions, fibroadenoma was the most common benign lesion 60 (48 \%) followed by Proliferative breast lesion without atypia inclusive of fibrocystic disease (30 cases; $24.4 \%$ ), this study is comparable to study by Faiyaz Ahmad [13] (41.07\%) followed by proliferative breast lesion without atypia (14.29\%) and Neha Kurmi Patel et al., [14] who reported $43.5 \%$ cases of fibroadenoma and $24.1 \%$ cases of Fibrocystic disease. Thus the present study is in concordance with the most other studies available.

We reported 43 cases of acute mastitis which is in contrast with the study of Neha Kurmi patel et al
( 4 cases) and Faiyaz ahmad et al (14 cases). This higher number of cases may be due to the age criteria in our study, cases of acute mastitis may be related to trauma during lactation. We observed 5 cases of fat necrosis, Faiyaz Ahmad et al observed 3 cases of the same.

Out of 200 cases, 20 cases were of Galactocele and 7 cases of Lactational adenoma. Galactocele showed benign ductal cell in the background of lipid droplets as vacuoles. Lactation adenoma showed cellular smear with minimal pleomorphism and foamy vacuolated cells. Our study is in concordance with Sharma M et al., [15] who reported 16 cases of galactocele and 5 cases of lactational adenoma in their study of breast lump during pregnancy and lactation.

In two cases $(3.8 \%)$ we found chitinous wall, vegetative nuclei with scattered histiocytes though hooklets were not seen and cases were reported as suspicious of Cysticercosis after excluding other diagnosis. Cysticercosis of the breast is rare and it should be considered as differential diagnosis for a lump in breast. Well formed epitheloid cell granulomas were found in 02 cases $(3.8 \%$ ) which were reported as Granulomatous Mastitis.

Hormonal changes before menopause and changes in breast. Malignancy was diagnosed in only two cases, both the females were around 45 year old, smears showed large pleomorphic ductal cells in cohesive clusters with many inflammatory cells in the background, lump in both cases were soft fleshy and well circumscribed, it was clinically mimicking benign lesion and FNAC helped in early diagnosis and treatment of these cases [16, 17]. In some epidemiological studies, ACE gene polymorphisms, including I/D polymorphism and few more genetic associations were found to be associated with increased Carcinoma Breast risk except the Multi-ethnic Cohort 
Study. So, it's always better to opt for higher ancillary tests like genetic polymorphism [18].

\section{CONCLUSION}

Fine needle aspiration cytology is diagnostic tool which is rapid and effective method for preoperative diagnosis to relieve the anxiety of premenopausal patient regarding any sort of breast lump and also for post-operative follow up of breast lumps to ensure the recurrences. Benign lesion are commoner than malignant lesion, fibroadenoma is the commonest entity, as 20-30 years are reproductive age group, pathologist must be aware of galactocele, lactating adenoma, and acute mastitis, which are expected in breast lump during pregnancy and lactation. Although rare cysticercoids must be considered in the differential diagnosis of breast lump, FNAC was invaluable in the diagnosis of less common malignant tumour like Ductal carcinoma, which clinically and radiologically mimics as benign lesion. Further evaluation is required if FNAC findings are suspicious of malignancy like histopathology and immunohistochemistry for confirmation of the diagnosis and proper management.

\section{REFERENCES}

1. Koss, L. (1992). Diagnostic cytology 4th edition. Philadelphia: Lippincott Williams \& Wilkins; 611.

2. Place, R., Velanovich, V., \& Carter, P. (1993). Fine needle aspiration in the clinical management of mammary masses. Surgery, gynecology \& obstetrics, 177(1), 7-11.

3. Dennison, G., Anand, R., Makar, S. H., \& Pain, J. A. (2003). A prospective study of the use of fineneedle aspiration cytology and core biopsy in the diagnosis of breast cancer. The breast journal, 9(6), 491-493.

4. Muddegowda, P. H., Lingegowda, J. B., Kurpad, R., Konapur, P. G., Shivarudrappa, A. S., \& Subramaniam, P. M. (2011). The value of systematic pattern analysis in FNAC of breast lesions: 225 cases with cytohistological correlation. Journal of Cytology/Indian Academy of Cytologists, 28(1), 13-19.

5. Mansoor, I. (2001). Profile of female breast lesions in Saudi Arabia. Journal-Pakistan Medical Association, 51(7), 243-246.

6. Berner, A., \& Sauer, T. (2011). Fine-needle aspiration cytology of the breast. Ultrastruct Pathol. 35:162-7.

7. Gerhard, R., \& Schmitt, F. C. (2014). Liquidbased cytology in fine-needle aspiration of breast lesions: a review. Acta cytologica, 58(6), 533-542.
8. Mohammed, A. Z., Edino, S. T., Ochicha, O., \& Alhassan, S. U. (2005). Value of fine needle aspiration biopsy in preoperative diagnosis of palpable breast lumps in resource-poor countries: A Nigerian experience. Ann Afr Med. 4:19-22.

9. Meena, S. P., Hemrajani, D. K., \& Joshi, N. (2006). A comparative and evaluative study of cytological and histological grading system profile in malignant neoplasm of breast--an important prognostic factor. Indian journal of pathology \& microbiology, 49(2), 199-202.

10. Reddy, D. G., \& Reddy, C. R. (1958). Carcinoma of the breast, its incidence and histological variants among South Indians. Indian journal of medical sciences, 12(4), 228-234.

11. Rocha, P. D., Nadkarni, N. S., \& Menezes, S. (1997). Fine needle aspiration biopsy of breast lesions and histopathologic correlation. An analysis of 837 cases in four years. Acta cytologica, 41(3), 705-712.

12. Zuk, J. A., Maudsley, G. I. L. L. I. A. N., \& Zakhour, H. D. (1989). Rapid reporting on fine needle aspiration of breast lumps in outpatients. Journal of clinical pathology, 42(9), 906-911.

13. Ahmad, F., Mittal, A., Verma, P., Kumar, A., Awasthi, S., \& Dutta, S. (2016). Cytomorphological Study of Palpable Breast Lumps: Spectrum of Lesions and Diagnostic Utility of FNAC. Annals of International Medical and Dental Research, 2(4), 237-241.

14. Patel, N. K., Patel, L. M., \& Patel, S. (2019). Cytological Evaluation of Palpable Breast Lumps: A Prospective Analysis of 84 Cases. JMSCR. 7(7):7-12.

15. Med, G. J. R. (2017). Cytological Evaluation of Breast Masses during Pregnancy and Lactation: A Retrospective Analysis. Glob J Reprod Med. 555593.

16. Bukhari, M. H., Arshad, M., Jamal, S., Niazi, S., Bashir, S., \& Bakhshi, I. M. (2011). Shaharyar. Use of fine-needle aspiration in the evaluation of breast lumps. Patholog Res Int, 2011, 689521.

17. Rosai \& Ackerman's Surgical Pathology $10^{\text {th }}$ edi vol. 11. Elsevier: 2011 Breast chapter 20 in Juan Rosai (ed) pg. 1600-1771.

18. Khan, S., \& Ahmad, S. Role of Angiotensin Converting Enzyme (ACE) Gene Polymorphism in Breast Cancer among North Indian Population. Annals of International Medical and Dental Research, 5(6), 17- 23. 